\title{
同期機等価回路定数の同定 一直流減衰電流を指数関数の和で近似する方法一
}

\begin{tabular}{|c|c|c|c|c|}
\hline 員 荒 & & 隆 & 裕 & (職業能力開発大) \\
\hline 員 & 間 & & & (大阪職業能力開発短期 \\
\hline 員 & & & & （職業能力開発大） \\
\hline
\end{tabular}

Identification of Element-Values in the Equivalent Circuit of Synchronous Machine - Method by Approximate Expression of D. C. Decaying Curren twith Exponential Function-

Takahiro Ara, Member (The Polytechnic University), Tsunaki Akima, Member (Osaka Polytechnic College), Shoichi Oda, Member (The Polytechnic University)

This paper is concerned with a new method that identifies the equivalent circuit constant of synchronous machines using D.C. decaying current. The procedure is as follows ;

(1) D.C. voltage is applied to the armature winding (two terminals with the third one open) of a stationary synchronous machine through a resistance. When two terminals are closed, the winding is shortcircuited and the current in the armature winding decays. The whole process of current decay is recorded.

(2) The current decay is approximated by the exponential function, and values of the index number and coefficient are identified with the least square method.

(3) The equivalent circuit constant is identified from the relationship which is formed between these constants and the exponential function.

The starting performance of synchronous motor with damper winding is calculated using the method and agrees with actual data.

The test capacity is needed about $0.1 \%$ of a starting capacity with $50 \%$ voltage.

キーワード：同期機, 等価回路定数, 始動特性, 直流隇衰電流

\section{1.まえがき}

同期機の最大出力，同期化力，過渡安定度，自己始動時 の始動特性などの動作特性を把握するためには，等価回路

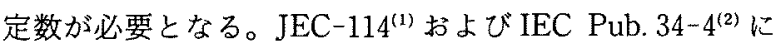
は,これら等価回路定数のうち電機子抵抗と直, 横軸の同 期リアクタンスの測定法が規格化されているが，界磁扔よ び始動 (制動) 巻線の抵抗と漏れリアクタンスなどの定数を 測定する方法は見当たらない。また，これら試験法は，交 流試験によって測定する方法であり，同期機の単機容量の 增大化は，試験設備の大容量化を伴い，製造工場において その大容量化に十分対応できなくなっている。このため小 容量電源を用いた静止試験によって同期機の等価回路定数 を精度良く測定する方法の確立が求められている。 小容量電源を用いた静止試験による回路定数の測定法と しては，交流電源を用いる場合と直流電源を用いる場合に
大別できる。

交流電源を用いる場合は, 可変周波数電源を用いて端子 加ら見た周波数特性を求め, これらを用いて最小二乗法に よって回路定数を同定する方法であり, IEEE Std $115 \mathrm{~A}^{(3)}$ に記載されている。この方法によって等価回路定数を精度 良く同定するためには, $1.0 \mathrm{~Hz}$ 以下の非常に低い周波数 まで可変できる電源を必要とする。また，低周波数領域で の周波数特性を精度良く测定することは一般に困難であ る。

一方，直流電源を用いる方法としては，電機子巻線二相 間に直流電源を接繶して電流を流した後この二相間を短 絡したときあるいは二相間に直流電圧をステップ的に印加 したときの過渡波形から回路定数を同定する方法が提案さ れている(4)(5)。これらは, 同期機諸定数 $\left(T_{d}^{\prime}, T_{d}^{\prime \prime}, T_{d 0}^{\prime \prime}, X_{d}\right.$, $X_{q}$ など)を求める理論式に基づき同定を行っている。

これらに対して筆者らが提案する方法は, 誘導機にも適 
用できる $\mathrm{T}$ 形等価回路の諸定数に関して，その理論的な 関係式に基づき同定を行っている。この方法は，まず，第 1 段階として端子間短絡時の電機子直流減衰電流を指数関 数の和で近似し，この関数の係数および指数を最小二乗法 で同定し，第 2 段階としてこれらと上述の端子間短絡時の 過渡現象回路(6)との関係式から最小二乗法によって等価 回路定数を同定する方法 ${ }^{(7)(8)}$ である(以下指数関数法と呼 ऊ)。

本論文では，供試機として始動巻線付き突極形同期電動 機の等価回路定数を同定している。この同定值を用いて同 期電動機が, 直流励磁なしで誘導電動機と同じ原理で始動 したときの始動特性を計算し，奏測值との比較・検討より 指数関数法による等洒回路定数同定法の妥当性を示してい る。

\section{2. 理論式の導出}

ここでは，静止した始動 (制動) 巻線付き突極形同期機の 等価回路定数を同定するための関係式の導出方法について 述べる。

同期機は, 電機子回路, 回転子回路を直軸回路(直軸成 分）と横軸回路(横軸成分)に分解して取り扱われる。これ ら, 直軸拉よび横軸の各回路は, 以下の手順で決定するこ とができる。まず，電機子巻線の二相間 $(U-V) に$ 単相交 流電源を接続し, 電機子巻線に低電圧を印加する。直軸回 路は, 回転子を移動させ界磁巻線間に接続した電流計の目 盛りが最大となる位置で回転子を固定した場合である。横 軸回路は、これが最小となる位置で回転子を固定した場合 である。

$\langle 2 \cdot 1\rangle$ 直軸回路の場合図 1 は, 電機子二相間に直 流電源を接続した場合の直軸回路である。界磁巻線の回路 は短絡されているものとする。まず，スイッチ SWが(1) のとき, 電機子二相間には一定電流 $I_{D C} か ゙$ 流れる。次に, SW を(2)に切り換えると減衰電流 $i_{1}$ が流れる。

SWを(1)から(2)へ切り換えたときのアーク電圧を無視す れば電圧および電流波形は, 図 2 となる。

この過渡状態における各回路の電圧方程式は,

$$
\begin{aligned}
& r_{a} i_{1}(t)+\left(L_{l}+M_{a d}\right) \frac{d i_{1}(t)}{d t} \\
& -M_{a d} \frac{d i_{2}(t)}{d t}-M_{a d} \frac{d i_{3}(t)}{d t}=0 \\
& -M_{a d} \frac{d i_{1}(t)}{d t}+r_{k d} i_{2}(t)+\left(L_{k d}+M_{a d}\right) \frac{d i_{2}(t)}{d t} \\
& +M_{a d} \frac{d \ddot{d}_{3}(t)}{d t}=0 \\
& -M_{a d} \frac{d i_{1}(t)}{d t}+M_{a d} \frac{d i_{2}(t)}{d t}+r_{f} i_{3}(t) \\
& +\left(L_{f}+M_{a d}\right) \frac{d i_{3}(t)}{d t}=0
\end{aligned}
$$

で表わされる(6)。

ただし， $r_{a}, L_{l}:$ 電機子巻線の抵抗，漏れインダ クタンス, $M_{a d}:$ 直軸励磁インダクタンス, $r_{k d}$,

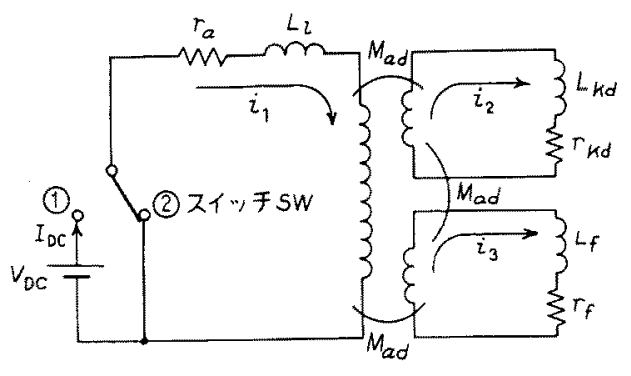

図 1 直軸回路

Fig. 1. Circuit of direct-axis.

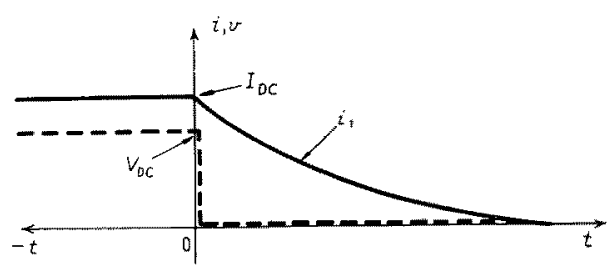

図 2 電压拈よび電流の変化

Fig. 2. Input voltage and current response.

$L_{k d}:$ 直軸始動 (制動) 巻線の抵抗，漏れインダク

タンス, $r_{f}, L_{f}:$ 界磁巻線の抵抗, 漏れインダク

タンス

$L_{1}, L_{2}, L_{3}$ は自己インダクタンスであり, 各巻線の漏れ インダクタンスとの間には， $L_{1}=L_{t}+M_{a d}, L_{2}=L_{k d}$ $+M_{a d}, L_{3}=L_{f}+M_{a d}$ の関係がある。また, 初期条件は $i_{1}(0)=I_{D C}, i_{2}(0)=i_{3}(0)=0$ である。

次に，(1)〜(3)式をラプラス変換し，電機子巻線を流 れる電流を求めると，(4)〜（７）式で表わされる。

$$
\begin{aligned}
I_{1}(p) & =\frac{\left(x p^{2}+y p+z\right) I_{D C}}{a p^{3}+b p^{2}+c p+d} \\
& =\frac{\left(x p^{2}+y p+z\right) I_{D C}}{a\left(p-m_{1}\right)\left(p-m_{2}\right)\left(p-m_{3}\right)} \\
& =\frac{A_{1}}{p-m_{1}}+\frac{A_{2}}{p-m_{2}}+\frac{A_{3}}{p-m_{3}}
\end{aligned}
$$

ただし，pはラプラス演算子である。

$$
\begin{aligned}
a= & L_{1} L_{2} L_{3}-\left(L_{1}+L_{2}+L_{3}\right) M_{a d}{ }^{2}+2 M_{a d}{ }^{3} \\
b= & r_{a} L_{2} L_{3}+r_{k d} L_{1} L_{3}+r_{f} L_{1} L_{2} \\
& -\left(r_{a}+r_{k d}+r_{f}\right) M_{a d}{ }^{2} \\
c= & r_{a} r_{k d} L_{3}+r_{k d} r_{f} L_{1}+r_{a} r_{f} L_{2} \\
d= & r_{a} r_{k d} r_{f} \\
x= & L_{1} L_{2} L_{3}-\left(L_{1}+L_{2}+L_{3}\right) M_{a d}{ }^{2}+2 M_{a d}{ }^{3} \\
y= & r_{k d} L_{1} L_{3}+r_{f} L_{1} L_{2}-\left(r_{k d}+r_{f}\right) M_{a d}{ }^{2} \\
z= & L_{1} r_{k d} r_{f}
\end{aligned}
$$

(6)式を逆変換すると隇衰電流 $i_{1}(t)$ は,

$$
i_{1}(t)=A_{1} \varepsilon^{m_{1} t}+A_{2} \varepsilon^{m_{2} t}+A_{3} \varepsilon^{m_{3} t}
$$

となる。

図 2 の隇衰電流を(8)式で近似すれば各指数関数の係数 $\left(A_{1}, A_{2}, A_{3}\right)$ および指数 $\left(m_{1}, m_{2}, m_{3}\right)$ は, 各時刻に拈ける 減衰電流の実測值との詔差の二莱和が最小となる方法によ 
って同定することができる。

次に各等価回路末知定数を同定するために，これら末知 定数を同定した指数関数の係数抢よび指数との関係を求め る。まず，(4)式と（5) 式の右辺を比較すると，

$$
\begin{aligned}
& -\frac{b}{a}=m_{1}+m_{2}+m_{3} \\
& \frac{c}{a}=m_{1} m_{2}+m_{3} m_{1}+m_{2} m_{3} \\
& -\frac{d}{a}=m_{1} m_{2} m_{3}
\end{aligned}
$$

の関係が得られる。次に(5)式と(6) 式の右辺を比較する と,

$$
\begin{aligned}
& \frac{x}{a}=\left(A_{1}+A_{2}+A_{3}\right) / I_{D C} \\
& \frac{y}{a}=-\left\{\left(m_{2}+m_{3}\right) A_{1}+\left(m_{1}+m_{3}\right) A_{2}\right. \\
& \left.+\left(m_{1}+m_{2}\right) A_{3}\right\} / I_{D C} \\
& \frac{z}{a}=\left(A_{1} m_{2} m_{3}+A_{2} m_{1} m_{3}+A_{3} m_{1} m_{2}\right) / I_{D C}
\end{aligned}
$$

の関係が得られる。

(9)〜 (14) 式は，等価回路未知定数で表現される非線形 連立方程式である。これらの式の各右辺は，同定した係数 $\left(A_{1}, A_{2}, A_{3}\right)$ 杍よび指数 $\left(m_{1}, m_{2}, m_{3}\right)$ を代入することによ って決定される。

また，各等価回路末知定数は，(9)〜 (14) 式の左辺に含 まれるので, 各式の左辺と右辺との差の二乗和が最小にな る方法によって同定することができる。

〈2・2〉横軸回路の場合 直軸回路の場合と同様に図 3 の横軸回路でスイッチ SWを(1)から(2)へ切り換えたと きの減衰電流を求める。

図 3 の各回路の電圧方程式は図 1 と同様に SW を切り 換えたときのアーク電圧を無視すれば,

$$
\begin{aligned}
& r_{a} i_{1}(t)+\left(L_{l}+M_{a q}\right) \frac{d i_{1}(t)}{d t}-M_{a q} \frac{d i_{2}(t)}{d t}=0 \\
& \cdots \ldots \ldots \ldots \ldots \ldots \ldots \ldots \ldots \ldots \ldots \ldots \ldots \ldots \ldots \ldots \ldots \ldots \ldots \ldots \ldots \ldots \\
& -M_{a q} \frac{d i_{1}(t)}{d t}+r_{k q} i_{2}(t)+\left(L_{k q}+M_{a q}\right) \frac{d i_{2}(t)}{d t}=0
\end{aligned}
$$

で表わされる。

ただし， $r_{a}, L_{l}:$ 電機子巻線の抵抗, 漏れインダ

クタンス, $M_{a q}$ : 横軸励磁インダクタンス, $r_{k q}$,

$L_{k q}$ : 横軸始動巻線の抵抗, 漏れインダクタンス

$L_{1}, L_{2}$ は自己インダクタンスであり, $L_{1}=L_{1}+M_{a q}, L_{2}$ $=L_{k q}+M_{a q}$ の関係がある。また, 初期条件は $i_{1}(0)=I_{D C}$,

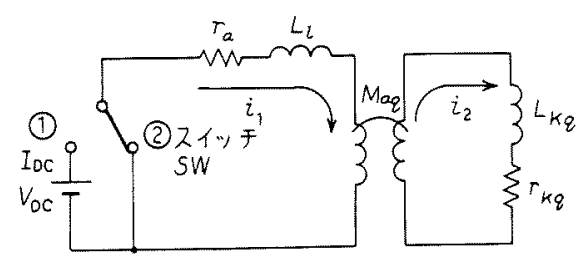

図 3 横軸回路

Fig. 3. Circuit of quadrature-axis. $i_{2}(0)=0$ である。

(15)式および(16)式をラプラス変換して電機子巻線を流 れる電流を求めると，次式で表わされる。

$$
\begin{aligned}
I_{1}(p) & =\frac{(x p+y) I_{D C}}{a p^{2}+b p+c} \cdots \ldots . . \\
& =\frac{(x p+y) I_{D C}}{a\left(p-m_{1}\right)\left(p-m_{2}\right)} \\
& =\frac{A_{1}}{p-m_{1}}+\frac{A_{2}}{p-m_{2}}
\end{aligned}
$$

ただし, $a=L_{1} L_{2}-M_{a q}{ }^{2}, b=L_{1} r_{k q}+L_{2} r_{a}, c=$ $r_{a} r_{k q}, x=L_{1} L_{2}-M_{a q}{ }^{2}, y=L_{1} r_{k q}$

直軸回路の場合と同様に(19)式において，ラプラス逆変 換すると電機子巻線を流れる減衰電流の式は,

$$
i_{1}(t)=A_{1} \varepsilon^{m_{1} t}+A_{2} \varepsilon^{m_{2} t}
$$

となる。

これら $m_{1}, m_{2}, A_{1}, A_{2}$ と $a, b, c, x, y$ の関係を求める ¿,

$$
\begin{aligned}
& \frac{b}{a}=-\left(m_{1}+m_{2}\right) \cdots \cdots \cdots \cdots \\
& \frac{c}{a}=m_{1} m_{2} \cdots \cdots \cdots \cdots \cdots \cdots \cdots \\
& \frac{x}{a}=\left(A_{1}+A_{2}\right) / I_{D C} \cdots \cdots \cdots \cdots \\
& \frac{y}{a}=-\left(A_{1} m_{2}+A_{2} m_{1}\right) / I_{D C}
\end{aligned}
$$

が得られる。

直軸回路の場合と同様, $A_{1}, A_{2}, m_{1}, m_{2}$ は横軸回路にお ける減衰電流を $(20)$ 式と近似し, 実測值から最小二乗法に よって同定できる。次に，これら定数を(21)〜 (24)式の右 辺に代入し，横軸等価回路の未知定数を変化させたときの 左辺と右辺との差の二乗和が最小になる方法によってこれ ら末知定数を同定できる。

なお，これら $A_{1}, A_{2}, m_{1}, m_{2}$ と未知の等価回路定数との 関係式は，(17)〜(19) 式より容易に求めることができる。 これら関係式を (20) 式へ代入し，末知定数を変化させたと きの各時刻における $i(t)$ と実測値との差の二乗和が最小 になる方法によって同定することもできる。

\section{3. 同定手順}

等価回路末知定数は，前述したように二段階の手順によ って同定している。図 4 および図 5 の同定手順は，直軸等 価回路の場合を例として示している。

第 1 段階は, 図 4 に示すように実測した直流減衰電流か ら (8) 式の指数関数の係数 $\left(A_{1}, A_{2}, A_{3}\right)$ おょび指数 $\left(m_{1}\right.$, $\left.m_{2}, m_{3}\right)$ を同定する。

これは，(8)式により $i_{1}(t)$ を計算し，その時刻の実測 值 $i(t)$ との差の二乗 $\left(i(t)-i_{1}(t)\right)^{2}$ を作り, これを各時刻 について加算した誤差評価関数 $\Delta \alpha$ に対して，これが最小 となるよう未知定数 $\left(A_{3}\right.$ を除き $A_{1}, A_{2}, m_{1}, m_{2}, m_{3}$ ，これ らを $X(K), K=1 \sim 5$ で表わす)の值を変化しこれを同定 する。未知定数は, 初期値として十分大きな值を仮定し, 


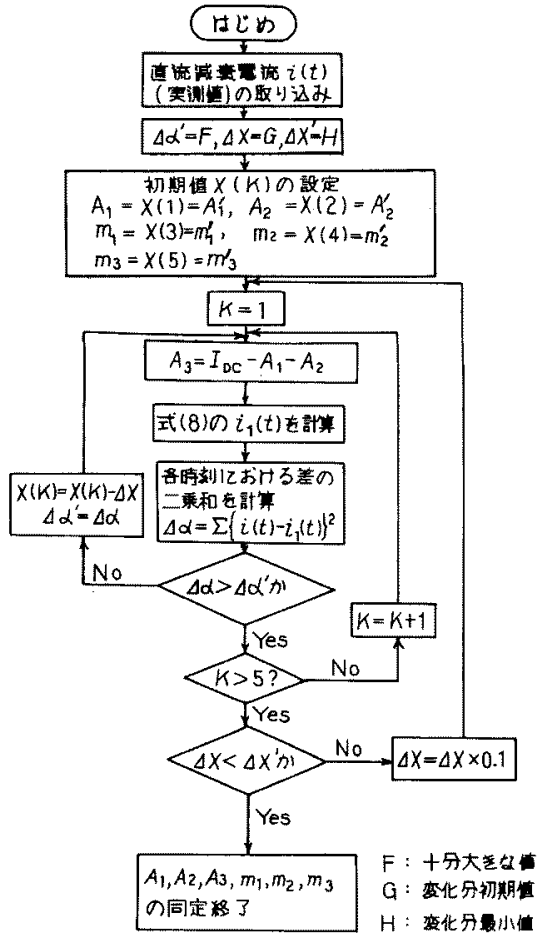

図 4 指数関数の係数の同定手順

Fig. 4. Identification method of values in exponential function.

各定数を一つずつ変化させ, 各定数 $X(K)$ の一定変化分 $\Delta X$ を減じながら $\Delta \alpha$ の最小化を行い，これが一巡したら 一定変化分 $\Delta X$ の値を 1 析だけ小さくし，末知定数に対 して必要な精度まで $\Delta X$ の析数を下げ同定を終了する。

第 2 段階では，まず，(9)〜 (14) 式の右辺に第 1 段階で 同定した $A_{1} \sim A_{3}, m_{1} \sim m_{3}$ ，および $I_{D C}$ を代入する。一 方, 左辺には未知定数 $\left(M_{a d}, L_{k d}, r_{k d}, L_{f}, r_{f}\right)$ お よび電機 子巻線抵抗 $r_{a}$, 電機子漏れインダクタンス $L_{l}$ を $(7)$ 式に 適用して得た $a \sim d, x \sim z$ を代入して，各式の $B_{i}=$ (左 辺一右辺 $)^{2},(i=1 \sim 6)$ を計算する。さらに重み係数 $C_{n}$ として, $C_{n}=\left(B_{1} \sim B_{6}\right.$ の最大值 $) / B_{n}, \quad(n=1 \sim 6)$ を定義 し, 愦差評価関数 $\Delta \beta$ として, $\Delta \beta=\Sigma\left\{(\text { 左辺一右辺 })^{2} \times\right.$ $\left.C_{n}\right\} ，(\Sigma は(9) \sim(14)$ 式の合計の意味)を作り，これが最 小となるように末知定数の值を変化し，これを同定する。

$\Delta \beta$ の最小化は, 未知定数に対して, 第 1 段階と同様な 手法を使用するので説明を省略する。重み係数 $\left(C_{1} \sim C_{6}\right)$ は，(9) （14) 式の各式の(左辺一右辺)の二乗の析数をそ ろえ，各式とも同等の重みでの評洒ができるので，短い計 算時間での精度の向上が計られる。

横軸等価回路についても同様な手順で同定するが，一般 に減衰電流は二つの指数関数の和 ((20) 式参照)で表わされ るので，同定は容易であり，説明を省略する。

$r_{a}$ は, 図 1 の回路でスイッチが(1)の状態での電圧・電流 より求めることができる。また，Llは，ある值に仮定し ている。これは, 同定した $A_{1} \sim A_{3}, m_{1} \sim m_{3}$ が一定である 加ら $L_{l}$ の值により一義的に決まる他の定数が存在し， $L_{l}$

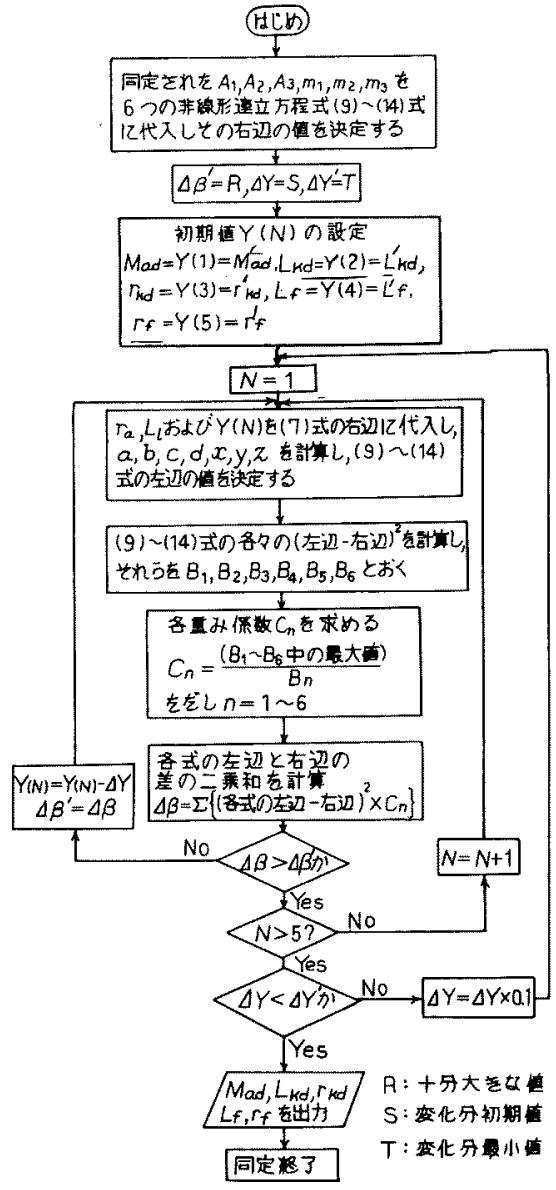

図 5 等価回路定数同定手順

Fig. 5. Identification method of constants in equivalent circuit.

は任意の值に仮定できるからである(9)。

\section{4. 等価回路定数の同定例および評価}

〈4・1〉等価回路定数の同定 低減電圧始動時におい てインピーダンスを線形と近似できる始動巻線付き突極形 同期電動機 (表 1 ) を供試機として, これの等価回路定数を 同定した。

直流減衰電流試験は，回転子を直軸あるいは横軸の位置 に固定し，直軸に扔いては界磁巻線を短絡した場合 $(K=$ 1）および界磁回路の抵抗が界磁巻線抵抗の 10 倍となるよ う外部抵抗によって短絡した場合 $(K=10)$, 横軸において は界磁巻線を開放した状態で，図 6 に示す直流滅衰電流試 験回路による試験を実施した。

各, 直軸および横軸の直流減衰電流は, 試験電流 $I_{D C}=$ $5.0 \mathrm{~A}$ になるように制限抵抗 $R_{d i s}$ で調整し，水銀りレーを オン,オフしたときの $X-Y$ 間の電圧㧍よび電流を各々 ディジタル電圧計およびディジタルオシロスコープで測定 した。この直流減衰電流の試験回路の詳細については, 著 者らが先の論文 ${ }^{(10)}$ で記述している。

直流減衰電流は，直軸抒よび横軸いずれの場合も垂直分 
表 1 成層磁極突極形同期電動機仕様

Table 1. Specifications of laminated-pole synchronous motor.

\begin{tabular}{|c|c|c|c|}
\hline 相 数 & 3 & 極 数 & 4 \\
\hline 定格容量 & $10 \mathrm{kVA}$ & ギャップ (平等) & $5.0 \mathrm{~mm}$ \\
\hline 定格電圧 & $200 \mathrm{~V}$ & 1 極の界磁巻回数 & 378 回 \\
\hline 定格電流 & $31.9 \mathrm{~A}$ & 界磁並列回路数 & 1 \\
\hline 周波数 & $50 \mathrm{~Hz}$ & 㧘機子龹線血列有効導体数 & 177.2 本 \\
\hline
\end{tabular}

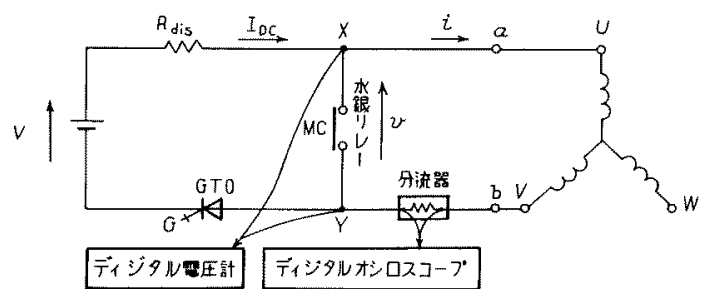

図 6 直流隇衰試験回路

Fig. 6. Test circuit.

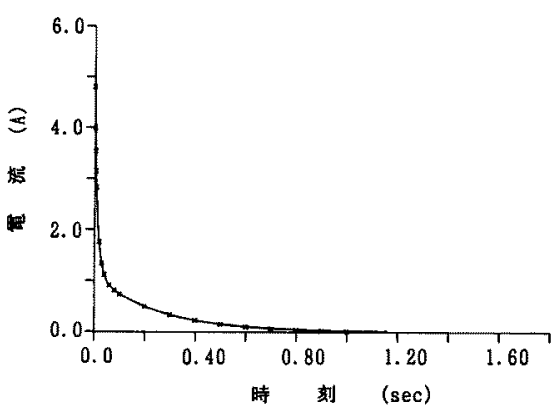

図 7 直軸減衰電流

Fig. 7. DC dacaying current of direct-axis.

解能 12 bit, サンプリング時間 $10 \mu \mathrm{sec}$ で測定した。直流 減衰電流が零となるまでのデー夕数は, 直軸において界磁 巻線が短絡の場合では 115600 個, 外部抵抗短絡の場合で は 53700 個である。また, 横軸の場合は 36100 個である。 電機子巻線抵抗 $r_{a}$ は, 水銀リレーを短絡する前の電圧 $V_{D C}$ および電流 $I_{D C}$ から求めた。また電機子漏れインダク タンス $L$ は, 著者らが先の論文 ${ }^{(1)}$ で提案した方法での值 を用いた。

直軸, 横軸の等価回路末知定数は，これら減衰電流の実 測值, $I_{D C}, r_{a}, L_{l}$ を用いて, 図 4 , 図 5 の同定手順により 同定した。

図 7 は， $K=1$ におりる直軸減衰電流の実測值と $(8)$ 式 による計算值との比較である。実線は，図 4 の同定手順に よって同定した $A_{1}, A_{2}, A_{3}, m_{1}, m_{2}, m_{3}$ の值を(8)式へ代 入して求めた各時刻における減衰電流の計算值である。 印は，ディジタルオシロスコープによって湘定した実測値 である。減衰が急峻な時刻 $0 \sim 0.08 \mathrm{sec}$ の間での実測值と

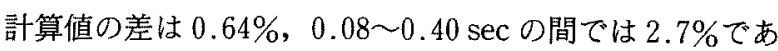
$\supset た$

図 8 は, 横軸減衰電流の実測值と計算值の比較である。 直軸の場合と同椂, 実線が同定した $A_{1}, A_{2}, m_{1}, m_{2}$ の値を

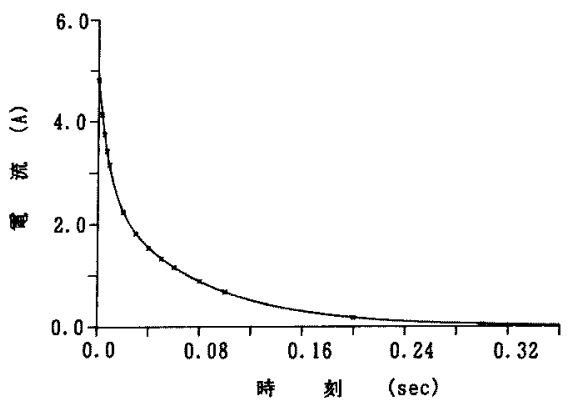

図 8 横軸減衰電流

Fig. 8. DC decaying current of quadrature-axis.

表 2 等価回路定数

Table 2. Constants in equivalent circuit.

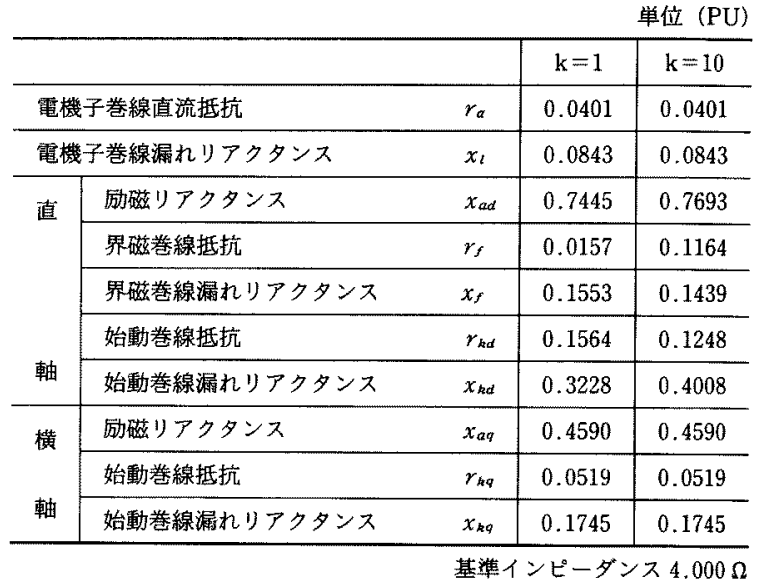

(20)式へ代入して求めた各時刻における電流の計算値， $\times$ 印が実測值である。実測值と計算值を比較すると，減衰が 急峻な時刻 $0 \sim 0.04 \mathrm{sec}$ の間でのこれらの差は $0.67 \%$, 0.04〜0.20 secでの差は $1.9 \%$ であった。

図 7, 図 8 より実測值と指数関数による近似がよく一致 していることがわかる。また， $K=10$ の計算值と実測值 の比較については省略するが，K=1の場合と同様よく一 致している。

次に，同定した $K=1$ 打よび $K=10$ におる $A_{1}, A_{2}$, $A_{3}, m_{1}, m_{2}, m_{3}$ を用いて, 図 5 の同定手順によって直軸等 価回路の未知定数を同定した。これら同定した二相間の值 を(9) （14）式の左辺に代入して，左辺と右辺とを比較す

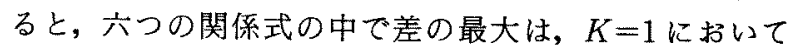
$0.04 \% ， K=10$ に㭁いて $0.01 \%$ あった。

直軸の場合と同樣な方法によって，横軸等価回路の未知 定数を同定した。これら同定した二相間の値を(21)〜(24) 式の左辺に代入して, 左辺と右辺とを比較すると, その差 の最大は 0.016\%であった。

これより，各等価回路末知定数が精度良く同定されてい ることが確認される。これら同定した值は，図6の端子 $U-V$ 間から見た二相間の值であるので表 2 の等価回路定 数ではこれらの同定值に $1 / 2$ を乗じて一相当たりとしてい る。 


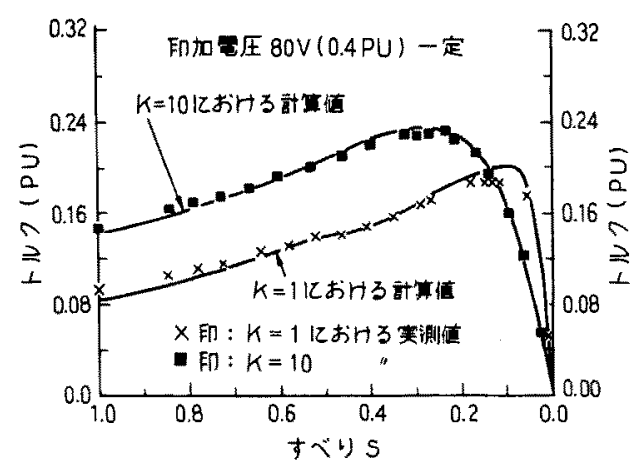

図 9 トルクーすべり特性

Fig. 9. Torque-slip curve.

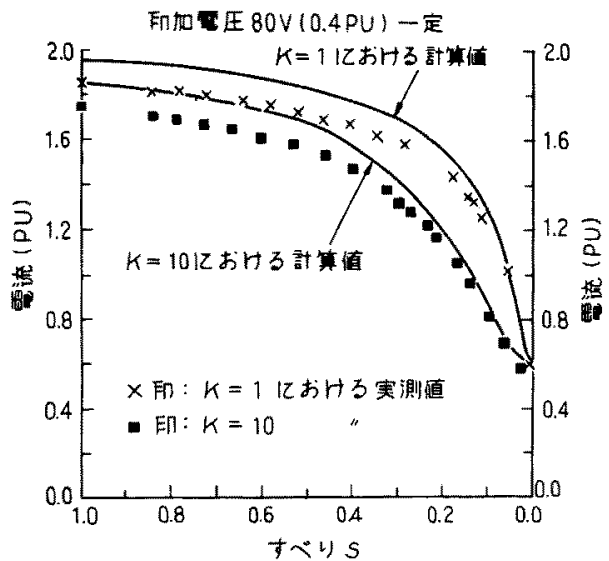

図 10 電流一すべり特性

Fig. 10. Current-slip curve.

表 2 の界磁巻線インピーダンスと始動巻線インピーダン スとの識別は，電機子漏れインダクタンス $L_{l}$ を変化させ て同定した $K=1, K=10$ の等価回路定数から行ってい $3^{(11)}$ 。

指数関数法で用いた直流減衰電流の実測 ゙゙ー夕(直軸回 路では $K=1$ )を用いて，先に著者らが提案したフーリエ 変換法(11)の手順によっても直軸および横軸の等価回路定

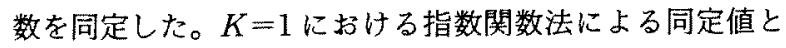
フーリエ変換法によるそれらとを比較すると最大の差は, 横軸の始動巻線抵抗で $2.3 \%$ あったた。同じ実測デー夕を 用いた二つの手法(指数関数法,フーリエ変換法)がほほ 致することにより，この同定法の妥当性が確認される。

〈4・2〉 始動特性 同定した等価回路定数を用いて, 印加電压 $80 \mathrm{~V}(0.4 \mathrm{PU})$ 一定とした場合の始動特性を計 算 ${ }^{(12)}$ し，実測值と比較・娭討した (付録参照)。

図 9 はトルクーず゙り特性, 図 10 は電流一すべり特性で

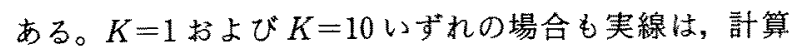
值であり，回印および×印は実測值である。これら実測値 の測定方法等については，すてに著者らの論文で述べてい るのてここでは省略する(13)。

計算值を実測值と比較するとその差の最大は，図 9 で $K=1$ のとき $7.9 \%$ (すべり $s=0.11$ ), $K=10$ のとき $2.7 \%$
(すべり $s=1.0$ )である。また図 10 では， $K=1$ のとき $7.5 \%$ (すべり $s=0.35$ )，K=10のとき $7.3 \%$ (すべり $s=$ 0.60)であった。

電機子漏れインダクタンス $L_{l}$ を変化させた場合につい ても，等価回路定数を同定し，始動特性を計算したが，計 算值はいずれの場合も一致した。これは, 電機子漏れイン ダクタンス $L l$ の值により一義的に決まる他の定数値が存 在し，Llは任意の值に仮定できるので，Llに対応する他 の定数は図 6 の端子 $U-V$ から見た回路定数として精密に 同定したことになる。

\section{5. と め}

直流減衰電流を指数関数近似することから同期機の等価 回路定数を同定する方法について述べた。ここで得られた 結果をまとめると以下のとおりである。

（1）本論文で提案した方法は，一次回路と鎖交する複 数の二次回路が存在する場合, 二乗誤差を最小にする反復 計算が複雑にならず，したがってこのような場合の等価回 路定数を同定する函めて有力な手法と考光られる。

（2）始動特性の計算值が，実測值とほほ一致すること から，本論文における等価回路定数の同定法の妥当性を確 認した。

な㧍, 直流減衰電流の実測值は, 試験電流 $5.0 \mathrm{~A}$ の值 を使用しており，同期電動機が定格電压の50\%電圧で始 動するとしたときの試験設備に対して，本法は，わずか $0.1 \%$ あり，当初の目的を達している。

おわりに本法は，誘導機の等価回路定数の同定にも基本 的に適用しうるものであり，その展望が開けた意味も大き いことを付け加えておく。

日ごろ御指導をいただく明治大学理工学部松瀬貢規教授 に深く感謝の意を表する次第である。

(平成 5 年 11 月 24 日受付, 同 6 年 11 月 10 日再受付)

\section{文献}

(1) JEC-114：電気学会電気規格調查会標準規格(昭 54)

(2) IEC Pub. 34-4: "Methods for Determining Synchronous Machine Quantities from Test" (1985)

(3) IEEE Std 115A: "IEEE Standard Procedures for Obtaining Synchronous Machine Parameters by Standstill Response Testing"

(4) P. J.Turner, D. C. Macdonald \& A. B. J. Reece: The D.C Decay Test for Determining Synchronous Machine Parameters: Measurement and Simulation, IEEE Transactions on Energy Conversion, 4, No.4 (1989)

(5) E.S. Boje, J. C. Balda, R.G. Harley \& R.C. Beck: TimeDomain Identification of Synchronous Machine Parameters from Simple Standstill Tests, IEEE Transactions on Energy Conversion, 5, No. 1 (1990)

（6）電気学会：電気工学ハンドブック, 電気学会, p. 696(昭 56)

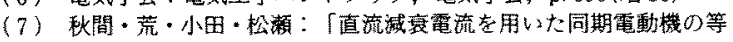
価回路定数算出法」，電気学会全大，703 (平 4)

（8）秋間・㐬・小田：「最小二乗法による同期機等価回路定数の同 定」, 電気学会回転機研資, RM-92-33 (平 4)

（9）山村：「交流モータの解析と制御」，才二厶社，P. 26(昭 63)

（10）荒・山本・小田・松瀨：「直流圾験法に上万同期電動機 0 始動特 性推定法」, 電学論 D, 112, 1 (平 4)

（11）荒・浅野・小田・松頛：「直流隇衰電流のフーリエ変換に上る同 期機等值回路定数の同定法」, 電学論 D, 113,6 (平 5 ) 
(12) C. CONCORDIA : Synchronous Machines (book), John Wiley \& Son 社, 1951

（13）荒・小田：「始動巻線付き同期電動機の始動特性推定法」, 電学 論 $\mathrm{D}, 110,8$ (平 2 )

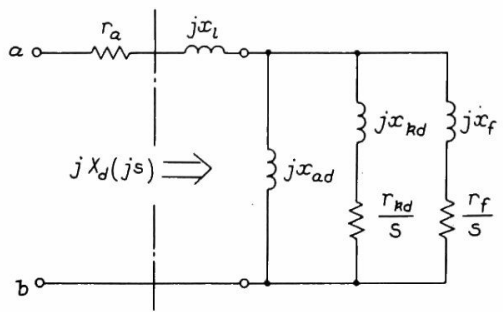

(a) 直軸等価回路

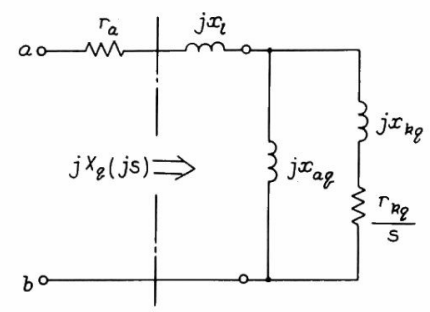

（b）横軸等価回路

付図 同期電動機始動時の直軸等価回路 aap. Fig. Equivalent circuit of synchronous motor for starting.

\section{付 録}

\section{1. 始動特性計算式}

トルクおよび電流は, 等価回路定数を使用して Park の 式から次のように導かれる(12)。

（1）直軸，横軸の電機子巻線全磁束鎖交数 $\phi_{d}(t), \phi_{q}(t)$

$$
\begin{aligned}
& \dot{\Phi}_{d}=\dot{I}_{d} X_{d}(j s) \\
& \phi_{d}(t)=\operatorname{Re}\left[\dot{\Phi}_{d} \varepsilon^{j s t}\right] \\
& \dot{\Phi}_{q}=\dot{I}_{q} X_{q}(j s)
\end{aligned}
$$

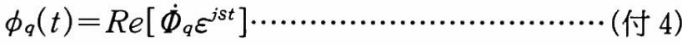

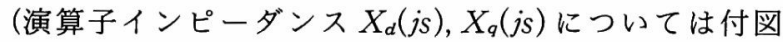
(a ), 付図 (b) 参照, $s$ は回転子のすべりである)

（2）直軸，横軸の始動電流 $i_{d}(t), i_{q}(t)$ およよ゙相電流 $i_{a}(t)$

$$
\dot{I}_{d}=\frac{\left\{r_{a}-j(1-2 s) X_{q}\right\} \dot{U}}{\left(r_{a}+j s X_{d}\right)\left(r_{a}+j s X_{q}\right)+(1-s)^{2} X_{d} X_{q}}
$$

$i_{d}(t)=\operatorname{Re}\left[\dot{I}_{d} \varepsilon^{j s t}\right]$

$$
\dot{I}_{q}=\frac{\left\{j r_{a}+(1-2 s) X_{d}\right\}}{\left(r_{a}+j s X_{d}\right)\left(r_{a}+j s X_{q}\right)+(1-s)^{2} X_{d} X_{q}}
$$

$i_{q}(t)=\operatorname{Re}\left[\dot{I}_{q} \varepsilon^{i s t}\right]$

$i_{a}(t)=i_{d}(t) \cos (1-s) t+i_{q}(t) \sin (1-s) t$

ただし， $X_{d}=X_{d}(j s), X_{q}=X_{q}(j s), \dot{U}$ は端子電圧で ある。

(3) 始動トルク $m(t)$
$m(t)=\phi_{q}(t) i_{d}(t)-\phi_{d}(t) i_{q}(t)$

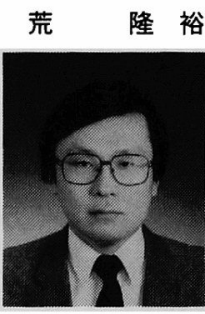

（正員）昭和 52 年 3 月職業訓練大学校電気工学 科卒業。同年 4 月, 㕍用促進事業団に入り, 浜 松総合高等職業訓練校勤務を経て, 昭和 55 年 4 月職業訓練大学校助手, 講師を経 $\tau$, 平成 4 年 4 月同助教授, 平成 5 年 4 月校名変更, 職業能 力開発大学校助教授, 現在にいたる。主として, 電気機械の解析に関する研究に従事。工学博士。 日本産業技術教育学会会員。IEEE 会員。

秋 間 紳 樹 (正員) 平成 4 年 3 月職業訓練大学校電気工学

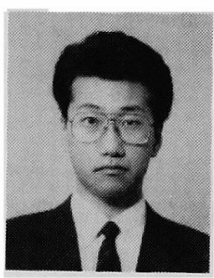
科卒業。同年 4 月同校研究課程入学。平成 5 年 4 月職業能力開発大学校に校名変更, 平成 6 年 3 月同校研究課程, 電気・情報専攻修了, 同年 4 月雇用促進事業団に入り, 大阪職業能力開発短 期大学校専任講師, 現在にいたる。

小田 荘 一 (正員) 昭和 28 年 3 月東京工業大学電気工学科

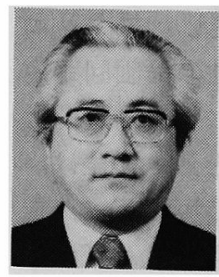
卒業。同年, 明電舎入社。昭和 48 年 4 月雇用促 進事業団に入り, 職業訓練大学校教授, 平成 5 年 4 月校名変更, 職業能力開発大学校教授, 長 期課程 (工学)部長, 現在にいたる。回転機の解 析, 関連技術, 回転機を含む小規模システムの シミュレーションおよび電動力応用の研究に従 事。技術士, 工学博士。IEEE 会員。 